\title{
Becoming Scotland: Screen Cultures in a Small Nation, 28-29 August 2014
}

\author{
ROBERT MUNRO, Queen Margaret University.
}

Held less than a month before Scotland voted on a referendum on independence from the United Kingdom, Becoming Scotland, organised by Michael Stewart and Douglas McNaughton from Queen Margaret University, utilised this unique moment in Scottish history to re-examine some of the ways in which Scotland has been represented in film and television. The conference's wideranging brief allowed for a variety of presentations considering the machinations of the film and television industries in Scotland; while others focused on (or challenged) the perceived representational tropes found therein. The timing of the conference necessitated a good amount of looking forward, particularly in the potential gains that could be made in the screen industries in an independent Scotland, although some also considered the potential losses that could be incurred and, significantly, the question of whether or not Scotland's screen industries have made the most of the resources already available to them within the Union.

Michael Stewart began the conference with a welcome speech, discussing the variety of themes upon which the conference would expand and introduced one of two keynote speakers at the conference, John Cook (Glasgow Caledonian University). Cook's talk - Echoes of the '45 addressed the work of English-born director Peter Watkins, whose influential 1964 BBC documentary-style film Culloden remains a seminal work in the representation of Scotland on television. Cook discussed how Watkins' ground-breaking work remains striking for its immediate, yet mediated, style of faux-reportage which allowed those present at the battle of Culloden in 1745, in which the Scottish Jacobite rebellion were crushed, to speak directly to camera in a way which confronts not only the nature of documentary and fiction, but also official accounts of British history. Cook's presentation then preceded to give an account of Watkins' subsequent career, the ways in which Scotland has historically been represented on television and what the future may hold for representations of Scotland, and particularly Scottish history, as the country nears a vote on independence. 
The first panel of the day - Scottish film: production, politics and identity - featured Robin MacPherson (Edinburgh Napier University), Jonny Murray (Edinburgh College of Art) and Nick Higgins (filmmaker), and the panel's diverse representation of policy, theory, education and practice was indicative of the ambitious scope of the conference. MacPherson gave an historical account of radical and alternative filmmaking in Scotland. Tracing the lineage of alternative filmmaking, MacPherson detailed the need for a reliable mainstream cinema against which those radical and engaged filmmakers could work around the fringes. Jonny Murray examined the ways in which contemporary Scottish film does, and doesn't, engage with notions of national identity. Considering Perfect Sense (2011) and Sunshine on Leith (2013), Murray set out a case for considering each film on its own merits, rather than trying to impose a homogenous national analytical framework upon Scottish cinema. Murray's ultimate contention, open to challenge it must be said, is that Sunshine on Leith's representation of contemporary Scotland is one at ease with Scotland's position in the Union, given its enthusiastic embrace of the central Scottish-English relationship of the film's protagonists. Rounding up the first panel, Nick Higgins presented an enlightening account of the production of his innovative documentary Northern Lights (2013). Higgins' crowd-sourced documentary encouraged people across Scotland to shoot footage of themselves, their friends and their locale and submit it to the project's website (www.wearenorthernlights.com). The resulting film, whittled down to 95 minutes from over 300 hours of footage, resulted in what Higgins terms "identity as assemblage" and documents a Scotland seen through a variety of lenses.

Jacqui Cochrane (Glasgow Caledonian University) began the next panel - Contemporary Scottish Drama - with an overview of the activities of BBC Scotland and the ways in which viewers in Scotland have responded to the dramatic television output of the corporation. Cochrane analysed whether viewer responses to Scottish television corresponded to the way television drama in Scotland has been thought of by the academy and industry itself. Cochrane found that many respondents did indeed feel Scottish television to be overly preoccupied with Highland scenery and urban crime, though that wasn't necessarily deemed in the negative way in which, perhaps, scholars view such representations of Scotland. Richard Butt (Queen Margaret University) followed with a detailed examination of classic television serial adaptations of Scottish literature. Butt's presentation examined the absence of Sir Walter Scott, Robert Louis Stevenson and J.M. Barrie from Scottish screens, especially interesting since all three where so often adapted for the screen previously. Finally from this panel, Robert Munro (Queen Margaret University) also examined the relationship between film and literature in Scotland. Munro provided a brief overview of the 
development of adaptation studies as a discipline, before outlining a case study analysis of the role of Irvine Welsh with Scotland's adaptation industry. Welsh's prominent role as internationally renowned author lends credibility to film adaptations of his work and, through an examination of Filth (2013), Munro highlighted some of the key ways in which Welsh's prominence was used in the film's production, marketing and reception.

The opening day was brought to a close by a practitioner panel organised and chaired by Irvine Allan (Queen Margret University). Allan introduced the panel with a talk about entry and progression within the Scottish film industry, drawing from his own experiences as short film maker. The panel, which featured Christeen Winford (filmmaker, Cormorant Productions), Peter Mackie Burns (filmmaker and writer) and Paul Welsh (filmmaker and producer, DigiCult), discussed at length the difficulties associated with getting films made in Scotland. The lack of agents resident in Scotland was cited as a primary reason for the perceived drain in filmmaking talent from the nation and the increasingly limited chances of short films getting exhibited, with the demise of the BBC's Tartan Shorts scheme much lamented, and also seen as a key barrier to nurturing a film industry in Scotland from the ground up.

Day two was initiated by the second keynote, Duncan Petrie (University of York), who spoke engagingly about the historical contribution Scots had made to the development of the British film and television industry. Petrie's talk was contextualised against the backdrop of the (then) forthcoming referendum on independence, examining how key Scottish individuals had helped to shape the histories of cinema and television in Britain. Biographies of well-known figures such as John Grierson and John Reith were discussed, in addition to the involvement of less well recognised figures such as John Maxwell, Stuart Hood, Colin Young and, more recently, Jeremy Isaacs. Petrie acknowledged that while this presentation shone a light on the Scottish influence on British film and television, it perhaps also reinforced the patriarchal perception of the upper echelons of the screen industries, in which the representation of women remains problematic.

The first panel of the morning examined media production in Scotland, as Robert Beveridge (University of Sassuolo) looked at the alleged failure of nerves by broadcasters and government over broadcasting in Scotland. Beverage argued that the BBC's representation of Scotland within its broader UK-wide remit remained problematic, questioning why BBC Scotland's flagship Scottish drama River City is not syndicated across the UK. He also pointed to the lack of ambition that Scottish governments have shown in pursuing a more representative broadcasting future, with SNP 
ministers baulking at the cost of setting up a digital Scottish channel. Lynn Whitaker (Glasgow Caledonian University) then discussed BBC Scotland's production of children's programmes, arguing that this exemplified a niche within the broader debates about Scottish television production. Whitaker argued that those working to produce children's programmes would never think of themselves as producing 'Scottish' content, and depended on the broad shoulders of the BBC network to offer any alternative to a market which is overwhelmingly saturated by programming from the United States. Finally, David Hutchison (Glasgow Caledonian University) examined the relationship between Holyrood and film production in Scotland. Hutchison discussed the role of Creative Scotland, and questioned the body's dedication (or lack thereof) towards film production, on which the body only spends $5 \%$ of its annual budget. Hutchison compared this figure to other national film bodies, with Canada's Telefilm and National Film Board of Canada's $\$ 50 \mathrm{~m}$ annual budget the equivalent to Creative Scotland spending $£ 12 \mathrm{~m}$ on the screen industries, four times the amount currently allocated.

The miserableness (or not) of Scottish filmmaking was the topic for the second panel of the day. David Manderson (University of the West of Scotland) and Eleanor Yule's (University of the West of Scotland) presentation drew upon their recently published book The Glass Half Empty: Scottish Miserablism to outline some of the key ways in which Scottish film has, in their view, repeatedly turned to the tropes associated with miserablism. These tropes included the sense of hopelessness which many characters are associated with, and their eventual flight or escape from Scotland, with Trainspotting's final act in London referenced. Manderson and Yule argued that films which engaged with this perceived miserablism in a post-modern and ironic manner were similarly guilty of perpetuating its disadvantages, something with which this author would disagree. In a similar vein, a heated but good natured debate followed Manderson and Yule's talk with some in the audience taking issue with the depiction of the reality of life for the working poor as necessarily 'miserablism'. Sarah Artt (Edinburgh Napier University) followed with an invigorating look at the monstrous feminine of Under the Skin and the ways in which the film provided another example of Scottish film's European cinema lineage. Bringing some levity to proceedings through her analysis of Local Hero and Highlander, Emily Torricelli (University of York) examined the post-modern appropriation of Highland mythology in both texts.

The first of the day's final two panels focused on Scottish television drama from the 1970s, with the merits of STV's Charles Endell Esq (1979) debated by Douglas McNaughton (University of Brighton); while BBC Scotland's Sutherland's Law (1973-1976) was the topic for Billy Smart's 
(University of Reading) paper. Rounding out the panel, Steve Cramer (Queen Margaret University) examined the representation of the uncanny in The Omega Factor (1979). Beginning the final panel, Richard Evans (Birkbeck, University of London) examined the uses of landscape in Scottish nonfiction films of the 1930 s to 1950 s, debating the extent to which such films played a part in the process of nation building through their representation of the nation's landscapes. Similarly, Kathryn Burnett (University of the West of Scotland) looked at the ways in which Scotland's islands were represented on screen and argued that they can provide an agency through which we can look at the idea of the nation. The final paper of the conference was given by Francesco Buscemi (Queen Margaret University), who also looked at the manner in which national identification can be performed on television. Using celebrity chef Jamie Oliver's cooking programme Jamie's Great Britain as an example, Buscemi talked through the variety of ways in which the programme framed the nation. The episode in which Oliver visited Scotland found the chef going on the hunt, rifle in hand, playing into the Victorian ideal of the Highlands. Additionally Oliver referenced the ancient traditions behind Scottish food, influenced by its Northerly Viking heritage which, again, reinforced the representation of Scotland as a mythic land out of time.

The conference provided a worthwhile and much valued contribution to the debate around the future of Scotland's screens, at a time when the nation was (and still is) collectively pondering exactly what Scotland and Scottishness means. The inclusivity of the conference, which allowed for contributions from film professionals, some of whom also work across academia, and early career researchers ensured a varied and vibrant few days, underpinned by the experience and knowledge of the wider academic community, which was exemplified by the two keynote speakers and the array of renowned academics also on the schedule.

Robert Munro is a second year PhD student at Queen Margaret University. Robert's research examines contemporary film and television adaptations of Scottish literature and the relationships between cultural policy, national identity and screen production in Scotland.

\section{Email: RMunro@qmu.ac.uk}

